\title{
The Roles of Motilin and Ghrelin in Gastrointestinal Motility
}

\author{
Tetsuro Ohno, Erito Mochiki, and Hiroyuki Kuwano \\ Department of General Surgical Science, Gunma University Graduate School of Medicine, 3-39-22 Showa-machi, \\ Maebashi 371-8511, Japan \\ Correspondence should be addressed to Tetsuro Ohno, tetsuro@med.gunma-u.ac.jp
}

Received 24 September 2009; Accepted 12 November 2009

Academic Editor: Akio Inui

Copyright (c) 2010 Tetsuro Ohno et al. This is an open access article distributed under the Creative Commons Attribution License, which permits unrestricted use, distribution, and reproduction in any medium, provided the original work is properly cited.

In structure, ghrelin resembles motilin. The two peptides are considered to be members of the motilin-ghrelin peptide family. Motilin is considered to be an endocrine regulator of the interdigestive migrating contractions, the fasted motor pattern in the gastrointestinal (GI) tract. It has been reported that ghrelin stimulates GI motility. The gastrokinetic capacity of ghrelin has been well documented in the rodent. However, there have been few positive reports of the gastrokinetic capacity of ghrelin in dogs. Some reports with human subjects have shown that an i.v. ghrelin injection accelerated gastric emptying of a meal and improved meal-related symptoms. These results suggest that ghrelin has potential as a prokinetic. However, it seems unlikely that plasma ghrelin would play a physiological role in these digestive physiological events and stimulate gastric emptying, as these outcomes would appear to be in contradiction with the suppression of the endogenous release of ghrelin after eating. The physiological roles of ghrelin need to be clarified.

\section{Introduction}

Ghrelin is a 28 -amino-acid peptide predominantly produced by endocrine cells in the oxyntic mucosa of the stomach as an endogenous ligand for the growth hormone $(\mathrm{GH})$ secretagogue receptor [1-4]. Initially, ghrelin was identified as having properties related to the release of GH [5]. Studies have shown that the infusion of ghrelin increases circulating plasma GH in rodents and humans [6-10]. However, other actions of ghrelin have emerged, such as its effects on the glucose metabolism and insulin release $[11,12]$, cardiovascular actions $[13,14]$, and food intake and control of energy balance $[15,16]$.

Structurally, ghrelin resembles motilin. Motilin is a 22amino-acid peptide synthesized from endocrine cells of the duodeno-jejunal mucosa. Motilin and ghrelin precursors share almost 50\% similarity in their amino-acid sequences, and the receptors of both peptides are part of the same family of $G$ protein-coupled receptors and share 53\% overall amino-acid sequence identity [17]. Based upon their structural similarity, the two peptides are now considered to be members of the new motilin-ghrelin peptide family.
Motilin regulates the interdigestive migrating contractions (IMC), the fasted motor pattern in the gastrointestinal (GI) tract [18]. Motilin plasma levels increase cyclically every 90-120 minutes during the interdigestive fasting period, and this cyclical release of motilin disappears after ingestion of a meal. These cyclical peaks of plasma motilin are synchronized to strong peristaltic contractions initiated from the stomach and migrating to the duodenum and small intestine. This pattern of migrating waves is known as the phase III contraction of IMC.

Ghrelin has also been reported to stimulate GI motility [19-22]. Ghrelin administration induces phase III-like contractions in the rat stomach [20]. Ghrelin also induces premature phase III contractions of IMC in the human stomach [21]. Vantrappen et al. [23] reported that motilin induces phase III contractions at a lower dose than ghrelin. On the other hand, high doses of motilin [24] and low doses of ghrelin [5] stimulate GH secretion. As indicated by Peeters [25], these results suggest that both peptides may cross-react with their receptors.

Endogenous ghrelin has been reported to be involved in mediating phase III-like contractions in the stomach of rats [26] and mice [27]. However, we revealed that ghrelin 


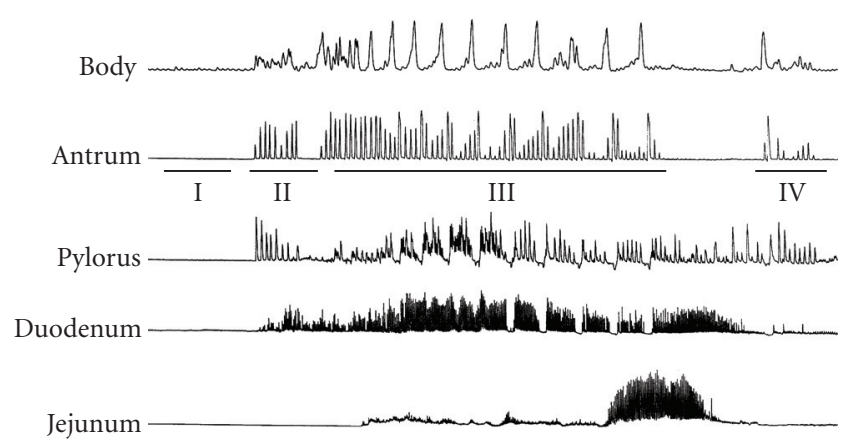

Figure 1: The typical four phases of IMC in the dog. Phase I: quiescence. Phase II: phase of irregular contractile activity. Phase III: intensive rhythmic contractions. Phase IV: rapid decline of activity before complete quiescence.

administration did not stimulate GI motility in conscious dogs [28]. Whether ghrelin activates GI motility in dogs and humans is controversial. This review focuses on the capacity of ghrelin to act on GI motility and compares the findings with those of motilin mainly in the dog.

\section{Motilin and Gastrointestinal Motility}

Because the motilin receptor exists as a pseudogene only in rodents $[29,30]$, studies on motilin regarding GI motility in animal models are scarce and have been limited to dogs. Motilin is considered to be a unique hormone playing a role in the interdigestive period, rather than, as in the case of most hormones, in the postprandial period. In the interdigestive state, GI motility is characterized by cycling IMC originating in the stomach and propagating along the small intestine. IMCs are assumed to have an important housekeeping role by forcefully pushing the content of the gut forward while cleaning the bowel of debris and bacteria that would otherwise accumulate and lead to bacterial overgrowth and compromise nutrient absorption from the small intestine, resulting in the sensation of hunger. The four phases of IMC were first described by Szurszewski [31]. Figure 1 shows the typical four phases of IMC in the dog. Phase I is quiescence. Phase II is irregular contractile activity. Phase III is characterized by intense, rhythmic contractions starting in the lower esophageal sphincter (LES) and stomach and migrating down the small bowel to the terminal ileum. In Phase IV, the activity rapidly declines until complete quiescence. Soon after motilin's discovery, it was suggested that motilin induces hunger contractions [32]. Itoh et al. [33] showed that the exogenous administration of motilin initiates premature phase III contractions in the stomach that are quite similar to the spontaneously occurring phase III contractions in dogs. This notion is supported by a study by Peeters et al. [34], who described phase III motor activities starting in the stomach or the upper duodenum that are associated with plasma motilin peaks, and another by Lee et al. [35], who reported that immunoneutralization of circulating motilin suppresses phase III contractions.
Many observations suggest the presence of motilin receptors on smooth muscle cells and on neurons of the GI tract. Itoh et al. [36] found that the effect of motilin on phase III activity in dogs was blocked by a 5 -hydroxytryptamine-3 $\left(5-\mathrm{HT}_{3}\right)$ antagonist. This finding suggests that the motilininduced signal may be mediated via $5-\mathrm{HT}_{3}$ receptors on the vagal afferents. The signal is then transmitted to the stomach via vagal efferents that induce the release of endogenous acetylcholine, since anticholinergic agents block the effect of motilin. On the other hand, in many in vitro studies, the induction of contractility by motilin was observed to be resistant to tetrodotoxin, which suggests that motilin receptors are present on smooth-muscle cells [37-39] and the contractile effects of motilin are mediated through a direct action on smooth muscle cells. Most evidence now points to the existence of motilin receptors on nerves as well as on muscles.

\section{Ghrelin and Gastrointestinal Motility}

As for the case of motilin, Tack et al. [21] demonstrated that, in humans, the administration of ghrelin induces a premature gastric phase III, which is not mediated through the release of motilin. Unlike motilin, ghrelin also induced phase III-like contractions in rats and mice [20, 26, 27]. These observations suggest that while the pharmacological effects of ghrelin were demonstrated, the involvement of ghrelin in the control of normal interdigestive motility was not.

In dogs, we revealed that an i.v. injection of synthesized canine ghrelin did not stimulate motor activity in the digestive tract (Figure 2), although it did stimulate the release of a GH [28]. Kudoh et al. [40] also reported that neither the growth hormone-releasing peptide- 2 nor ghrelin evoked GI contractions in the interdigestive state. These results differ from those obtained with studies using rodents. It is reasonable to expect that the action of a peptide will change from species to species. It remains to be determined whether ghrelin could be the surrogate of motilin in rats. The role of endogenous ghrelin in the regulation of phase III-like contractions remains unclear. To date, unlike the case of motilin [34], fluctuation of plasma ghrelin levels in synchrony with phase III activity fronts has not been reported.

\section{Motilin as a Prokinetic}

Motilin has a therapeutic potential as a pharmacological agent in stimulating gastric motility and accelerating gastric emptying of foods. Itoh et al. [41] first showed that erythromycin, a macrolide antibiotic, interacts with the motilin receptor and mimicked the effect of motilin on GI motility during the interdigestive state in dogs. In addition, in humans, erythromycin induces phase III activity [42], and the effect is dose-related in healthy volunteers and patients with diabetic gastroparesis [43]. Erythromycin derivatives devoid of antibiotic activity but with strong affinity for motilin receptors, also called motilides [44], were clinically 


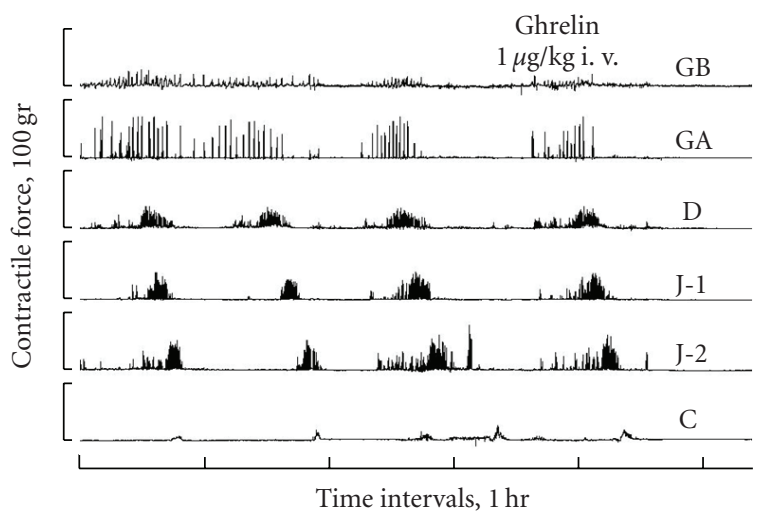

FIGURE 2: Examples of the effect of canine ghrelin at 1 and $10 \mu \mathrm{g}$ $\mathrm{kg} \mathrm{BW}^{-1}$ on the myoelectrical activity in a conscious dog, measured at a gastric body (GB), gastric antrum (GA), duodenum (D), jejunum (J-1 and J-2), and colon $(\mathrm{C})$. Ghrelin did not alter the interval and amplitude of phase III $\left(1 \mu \mathrm{g} \mathrm{kg} \mathrm{BW}{ }^{-1}\right)$ (from [28]).

tested. Clinical studies of ABT-229, one of the motilides, demonstrated the acceleration of gastric emptying in healthy volunteers; however, ABT-229 failed to improve symptoms in patients with functional dyspepsia and diabetic gastroparesis $[45,46]$. Disappointing results with ABT-229 decreased the interest in this field of research. However, it was pointed out that several factors associated with the drug (long halflife and/or tachyphylaxis [47] and possible effect on gastric accommodation [48-50]) and the study design (selection of patient population [51]) may have contributed to the negative outcome [52].

A new motilide, GM-611 or mitemcinal, led to promising new results. Takanashi et al. [53] confirmed mitemcinal as a selective and full motilin receptor agonist in in vitro pharmacological studies. Similarly to the case of motilin, intravenous administration of mitemcinal in dogs [54] stimulated interdigestive, as well as digestive, gastroduodenal motor activity, and its effect was blocked by the motilinreceptor antagonist GM-109. Colonic motility in dogs [55] could also be stimulated by mitemcinal given orally. Randomized controlled trials in 392 insulin-requiring diabetics revealed that symptoms attributable to gastroparesis could be ameliorated with $10 \mathrm{mg}$ mitemcinal twice daily than with a placebo and without inducing significant adverse effects [56].

\section{Ghrelin as a Prokinetic}

Masuda et al. [19] suggested that ghrelin could stimulate gastric contractions in rats. Trudel et al. [57] documented that ghrelin accelerates gastric emptying and the small intestinal transit of a liquid meal and is a strong prokinetic agent capable of reversing the postoperative gastric ileus in conscious rats. Poitras et al. [58] confirmed that the ghrelin analog RC-1139 is a potent gastrokinetic in rat: it reversed gastric postoperative ileus, even in the presence of opiates.

The gastrokinetic capacity of ghrelin had been well documented in the rodent. Trudel et al. [59] demonstrated that, as found earlier in rodents, ghrelin accelerates the normal

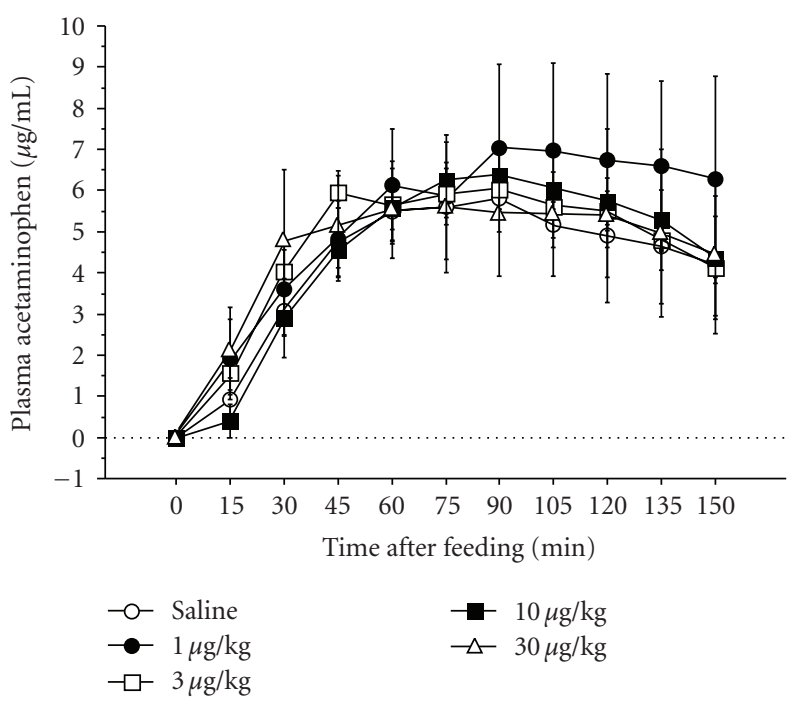

FIGURE 3: Effects of canine ghrelin on gastric emptying in conscious dogs. Saline and canine ghrelin were administered intravenously. Each symbol represents the mean \pm S.E.M. every 15 minutes in three dogs. Differences were not significant $(P>.05)$ (from [28]).

gastric emptying of a meal and was a potent prokinetic agent that improved postoperative gastric ileus in dogs. On the contrary, we [28] showed that an i.v. injection of ghrelin did not accelerate gastric emptying in dogs (Figure 3). To date, encouraging results of the gastrokinetic capacity of ghrelin in dogs are few.

In humans, Binn et al. [60] showed that an i.v. ghrelin injection accelerated gastric emptying of a meal even in the presence of deficient gastric innervation. Tack et al. [61] obtained similar results in which, in idiopathic gastroparesis, the administration of ghrelin enhanced gastric emptying and improved meal-related symptoms. These observations suggest the potential for ghrelin as a prokinetic. TZP-101, a synthetic ghrelin-receptor agonist, has been shown to be an active gastrokinetic agent in rats [62] and has already been tested in humans [63]. However, it seems difficult to believe that plasma ghrelin could play a physiological role in these digestive physiological events. Most evidence indicates that ghrelin plasma levels are high during the fasting period and decrease after meal ingestion. Most GI peptides increase after a meal. Motilin and ghrelin are the only hormones known to decrease in the postprandial period [64]. The observed biological action of the peptide, stimulation of meal gastric emptying, appears to be in contradiction with its endogenous release being suppressed after eating.

\section{Conclusion}

Ghrelin is of great interest, as is motilin, to the GI physiologist. The value of ghrelin as a prokinetic agent may soon be revealed. However, the physiological roles of ghrelin, especially in dogs and humans, need to be clarified. 


\section{References}

[1] H. Hosoda, M. Kojima, H. Matsuo, and K. Kangawa, "Ghrelin and des-acyl ghrelin: two major forms of rat ghrelin peptide in gastrointestinal tissue," Biochemical and Biophysical Research Communications, vol. 279, no. 3, pp. 909-913, 2000.

[2] G. Wang, H.-M. Lee, E. Englander, and G. H. Greeley Jr., "Ghrelin-not just another stomach hormone," Regulatory Peptides, vol. 105, no. 2, pp. 75-81, 2002.

[3] M. Kojima, H. Hosoda, and K. Kangawa, "Purification and distribution of ghrelin: the natural endogenous ligand for the growth hormone secretagogue receptor," Hormone Research, vol. 56, supplement 1, pp. 93-97, 2001.

[4] Y. Date, M. Kojima, H. Hosoda, et al., "Ghrelin, a novel growth hormone-releasing acylated peptide, is synthesized in a distinct endocrine cell type in the gastrointestinal tracts of rats and humans," Endocrinology, vol. 141, no. 11, pp. 42554261, 2000.

[5] M. Kojima, H. Hosoda, Y. Date, M. Nakazato, H. Matsuo, and K. Kangawa, "Ghrelin is a growth-hormone-releasing acylated peptide from stomach," Nature, vol. 402, no. 6762, pp. 656660, 1999.

[6] E. Arvat, L. Di Vito, F. Broglio, et al., "Preliminary evidence that Ghrelin, the natural GH secretagogue (GHS)-receptor ligand, strongly stimulates GH secretion in humans," Journal of Endocrinological Investigation, vol. 23, no. 8, pp. 493-495, 2000.

[7] R. Peino, R. Baldelli, J. Rodriguez-Garcia, et al., "Ghrelininduced growth hormone secretion in humans," European Journal of Endocrinology, vol. 143, no. 6, pp. R11-R14, 2000.

[8] K. Takaya, H. Ariyasu, N. Kanamoto, et al., "Ghrelin strongly stimulates growth hormone (GH) release in humans," Journal of Clinical Endocrinology and Metabolism, vol. 85, no. 12, pp. 4908-4911, 2000.

[9] L. M. Seoane, S. Tovar, R. Baldelli, et al., "Ghrelin elicits a marked stimulatory effect on GH secretion in freely-moving rats," European Journal of Endocrinology, vol. 143, no. 5, pp. R7-R9, 2000.

[10] V. Tolle, P. Zizzari, C. Tomasetto, M.-C. Rio, J. Epelbaum, and M.-T. Bluet-Pajot, "In vivo and in vitro effects of ghrelin/motilin-related peptide on growth hormone secretion in the rat," Neuroendocrinology, vol. 73, no. 1, pp. 54-61, 2001.

[11] F. Broglio, E. Arvat, A. Benso, et al., "Ghrelin, a natural GH secretagogue produced by the stomach, induces hyperglycemia and reduces insulin secretion in humans," Journal of Clinical Endocrinology and Metabolism, vol. 86, no. 10, pp. 5083-5086, 2001.

[12] M. K. Reimer, G. Pacini, and B. Ahren, "Dose-dependent inhibition by ghrelin of insulin secretion in the mouse," Endocrinology, vol. 144, no. 3, pp. 916-921, 2003.

[13] I. Bedendi, G. Alloatti, A. Marcantoni, et al., "Cardiac effects of ghrelin and its endogenous derivatives des-octanoyl ghrelin and des-Gln14-ghrelin," European Journal of Pharmacology, vol. 476, no. 1-2, pp. 87-95, 2003.

[14] N. Nagaya and K. Kangawa, "Ghrelin, a novel growth hormone-releasing peptide, in the treatment of chronic heart failure," Regulatory Peptides, vol. 114, no. 2-3, pp. 71-77, 2003.

[15] A. Asakawa, A. Inui, T. Kaga, et al., "Antagonism of ghrelin receptor reduces food intake and body weight gain in mice," Gut, vol. 52, no. 7, pp. 947-952, 2003.

[16] A. M. Wren, L. J. Seal, M. A. Cohen, et al., "Ghrelin enhances appetite and increases food intake in humans," Journal of Clinical Endocrinology and Metabolism, vol. 86, no. 12, pp. 5992-5995, 2001.
[17] P. Poitras and T. L. Peeters, "Motilin," Current Opinion in Endocrinology, Diabetes and Obesity, vol. 15, no. 1, pp. 54-57, 2008.

[18] Z. Itoh, "Motilin and clinical application," Peptides, vol. 18, no. 4, pp. 593-608, 1997.

[19] Y. Masuda, T. Tanaka, N. Inomata, et al., "Ghrelin stimulates gastric acid secretion and motility in rats," Biochemical and Biophysical Research Communications, vol. 276, no. 3, pp. 905908, 2000.

[20] K. Fujino, A. Inui, A. Asakawa, N. Kihara, M. Fujimura, and M. Fujimiya, "Ghrelin induces fasted motor activity of the gastrointestinal tract in conscious fed rats," Journal of Physiology, vol. 550, no. 1, pp. 227-240, 2003.

[21] J. Tack, I. Depoortere, R. Bisschops, et al., "Influence of ghrelin on interdigestive gastrointestinal motility in humans," Gut, vol. 55, no. 3, pp. 327-333, 2006.

[22] T. Kitazawa, B. De Smet, K. Verbeke, I. Depoortere, and T. L. Peeters, "Gastric motor effects of peptide and non-peptide ghrelin agonists in mice in vivo and in vitro," Gut, vol. 54, no. 8, pp. 1078-1084, 2005.

[23] G. Vantrappen, J. Janssens, T. L. Peeters, S. R. Bloom, N. D. Christofides, and J. Hellemans, "Motilin and the interdigestive migrating motor complexes in man," Digestive Diseases and Sciences, vol. 24, no. 7, pp. 497-500, 1979.

[24] W. K. Samson, M. D. Lumpkin, G. Nilaver, and S. M. McCann, "Motilin: a novel growth hormone releasing agent," Brain Research Bulletin, vol. 12, no. 1, pp. 57-62, 1984.

[25] T. L. Peeters, "Central and peripheral mechanisms by which ghrelin regulates gut motility," Journal of Physiology and Pharmacology, vol. 54, supplement 4, pp. 95-103, 2003.

[26] H. Ariga, K. Tsukamoto, C. Chen, C. Mantyh, T. N. Pappas, and T. Takahashi, "Endogenous acyl ghrelin is involved in mediating spontaneous phase III-like contractions of the rat stomach," Neurogastroenterology \& Motility, vol. 19, no. 8, pp. 675-680, 2007.

[27] J. Zheng, H. Ariga, H. Taniguchi, K. Ludwig, and T. Takahashi, "Ghrelin regulates gastric phase III-like contractions in freely moving conscious mice," Neurogastroenterology \& Motility, vol. 21, no. 1, pp. 78-84, 2009.

[28] T. Ohno, Y. Kamiyama, R. Aihara, et al., "Ghrelin does not stimulate gastrointestinal motility and gastric emptying: an experimental study of conscious dogs," Neurogastroenterology \& Motility, vol. 18, no. 2, pp. 129-135, 2006.

[29] J. Hill, P. Szekeres, A. Muir, and G. J. Sanger, "Molecular, functional and cross-species comparisons between the receptors for the prokinetic neuropeptides, motilin and ghrelin," Gastroenterology, vol. 122, supplement 1, p. A54, 2002.

[30] J. Aerssens, I. Depoortere, L. Thielemans, A. Mitselos, B. Coulie, and T. L. Peeters, "The rat lacks functional genes for motilin and the motilin receptor," Neurogastroenterology \& Motility, vol. 16, p. 841, 2004.

[31] J. H. Szurszewski, "A migrating electric complex of canine small intestine," The American Journal of Physiology, vol. 217, no. 6, pp. 1757-1763, 1969.

[32] Z. Itoh, I. Aizawa, S. Takeuchi, and E. F. Couch, "Hunger contractions and motilin," in Proceedings of the 5th International Symposium on Gastrointestinal Motility, G. Vantrappen, Ed., pp. 48-55, Herentals, Belgium, 1975.

[33] Z. Itoh, R. Honda, K. Hiwatashi, et al., "Motilin induced mechanical activity in the canine alimentary tract," Scandinavian Journal of Gastroenterology, vol. 11, supplement 39, pp. 93-110, 1976. 
[34] T. L. Peeters, G. Vantrappen, and J. Janssens, "Fasting plasma motilin levels are related to the interdigestive motility complex," Gastroenterology, vol. 79, no. 4, pp. 716-719, 1980.

[35] K. Y. Lee, T. M. Chang, and W. Y. Chey, "Effect of rabbit antimotilin serum on myoelectric activity and plasma motilin concentration in fasting dog," The American Journal of Physiology, vol. 245, no. 4, pp. G547-G553, 1983.

[36] Z. Itoh, A. Mizumoto, Y. Iwanaga, N. Yoshida, K. Torii, and $\mathrm{K}$. Wakabayashi, "Involvement of 5-hydroxytryptamine 3 receptors in regulation of interdigestive gastric contractions by motilin in the dog," Gastroenterology, vol. 100, no. 4, pp. 901908, 1991.

[37] U. Strunz, W. Domschke, P. Mitznegg, et al., "Analysis of the motor effects of 13 norleucine motilin on the rabbit, guinea pig, rat, and human alimentary tract in vitro," Gastroenterology, vol. 68, no. 6, pp. 1485-1491, 1975.

[38] H. Adachi, N. Toda, S. Hayashi, et al., "Mechanism of the excitatory action of motilin on isolated rabbit intestine," Gastroenterology, vol. 80, no. 4, pp. 783-788, 1981.

[39] F. E. Lüdtke, H. Müller, and K. Golenhofen, "Direct effects of motilin on isolated smooth muscle from various regions of the human stomach," Pflugers Archiv European Journal of Physiology, vol. 414, no. 5, pp. 558-563, 1989.

[40] K. Kudoh, C. Shibata, Y. Funayama, et al., "The effect of growth hormone releasing peptide- 2 on upper gastrointestinal contractile activity and food intake in conscious dogs," Journal of Gastroenterology, vol. 44, no. 4, pp. 297-304, 2009.

[41] Z. Itoh, M. Nakaya, T. Suzuki, H. Arai, and K. Wakabayashi, "Erythromycin mimics exogenous motilin in gastrointestinal contractile activity in the dog," The American Journal of Physiology, vol. 247, no. 6, pp. G688-G694, 1984.

[42] T. Tomomasa, T. Kuroume, and H. Arai, "Erythromycin induces migrating motor complex in human gastrointestinal tract," Digestive Diseases and Sciences, vol. 31, no. 2, pp. 157161, 1986.

[43] J. Tack, J. Janssens, G. Vantrappen, et al., "Effect of erythromycin on gastric motility in controls and in diabetic gastroparesis," Gastroenterology, vol. 103, no. 1, pp. 72-79, 1992.

[44] Z. Itoh and S. Omura, "Motilide a new family of macrolide compounds mimicking motilin," Digestive Diseases and Sciences, vol. 32, pp. 915-920, 1987.

[45] N. J. Talley, M. Verlinden, W. Snape, et al., "Failure of a motilin receptor agonist (ABT-229) to relieve the symptoms of functional dyspepsia in patients with and without delayed gastric emptying: a randomized double-blind placebo-controlled trial," Alimentary Pharmacology and Therapeutics, vol. 14, no. 12, pp. 1653-1661, 2000.

[46] N. J. Talley, M. Verlinden, D. J. Geenen, et al., "Effects of a motilin receptor agonist (ABT-229) on upper gastrointestinal symptoms in type 1 diabetes mellitus: a randomised, double blind, placebo controlled trial," Gut, vol. 49, no. 3, pp. 395401, 2001.

[47] L. Thielemans, I. Depoortere, J. Perret, et al., "Desensitization of the human motilin receptor by motilides," Journal of Pharmacology and Experimental Therapeutics, vol. 313, no. 3, pp. 1397-1405, 2005.

[48] J. Tack, H. Piessevaux, B. Coulie, P. Caenepeel, and J. Janssens, "Role of impaired gastric accommodation to a meal in functional dyspepsia," Gastroenterology, vol. 115, no. 6, pp. 1346-1352, 1998.
[49] I. M. C. Kamerling, A. D. van Haarst, J. Burggraaf, et al., "Exogenous motilin affects postprandial proximal gastric motor function and visceral sensation," Digestive Diseases and Sciences, vol. 47, no. 8, pp. 1732-1736, 2002.

[50] R. Cuomo, P. Vandaele, B. Coulie, et al., "Influence of motilin on gastric fundus tone and on meal-induced satiety in man: role of cholinergic pathways," American Journal of Gastroenterology, vol. 101, no. 4, pp. 804-811, 2006.

[51] R. W. McCallum, O. Cynshi, T. Abell, et al., "Efficacy of mitemcinal, a motilin agonist, on gastrointestinal symptoms in patients with symptoms suggesting diabetic gastropathy: a randomized, multi-center, placebo-controlled trial," Alimentary Pharmacology and Therapeutics, vol. 26, no. 1, pp. 107116, 2007.

[52] J. Tack and T. L. Peeters, "What comes after macrolides and other motilin stimulants?" Gut, vol. 49, no. 3, pp. 317-318, 2001.

[53] H. Takanashi, K. Yogo, K.-I. Ozaki, H. Koga, Z. Itoh, and S. Omura, "In vitro pharmacological characterization of mitemcinal (GM-611), the first acid-resistant nonpeptide motilin receptor agonist, in smooth muscle of rabbit small intestine," Pharmacology, vol. 79, no. 3, pp. 137-148, 2007.

[54] K.-I. Ozaki, K. Yogo, H. Sudo, et al., "Effects of mitemcinal (GM-611), an acid-resistant nonpeptide motilin receptor agonist, on the gastrointestinal contractile activity in conscious dogs," Pharmacology, vol. 79, no. 4, pp. 223-235, 2007.

[55] K. Ozaki, H. Sudo, H. Muramatsu, et al., "Mitemcinal (GM611), an orally active motilin receptor agonist, accelerates colonic motility and bowel movement in conscious dogs," Inflammopharmacology, vol. 15, no. 1, pp. 36-42, 2007.

[56] R. W. McCallum, O. Cynshi, and US Investigative Team, "Efficacy of mitemcinal, a motilin agonist, on gastrointestinal symptoms in patients with symptoms suggesting diabetic gastropathy: a randomized, multi-center, placebo-controlled trial," Alimentary Pharmacology and Therapeutics, vol. 26, no. 1, pp. 107-116, 2007.

[57] L. Trudel, C. Tomasetto, M. C. Rio, et al., "Ghrelin/motilinrelated peptide is a potent prokinetic to reverse gastric postoperative ileus in rat," American Journal of Physiology, vol. 282, no. 6, pp. G948-G952, 2002.

[58] P. Poitras, W. J. Polvino, and B. Rocheleau, "Gastrokinetic effect of ghrelin analog RC-1139 in the rat: effect on postoperative and on morphine induced ileus," Peptides, vol. 26, no. 9, pp. 1598-1601, 2005.

[59] L. Trudel, M. Bouin, C. Tomasetto, et al., "Two new peptides to improve post-operative gastric ileus in dog," Peptides, vol. 24, no. 4, pp. 531-534, 2003.

[60] M. Binn, C. Albert, A. Gougeon, et al., "Ghrelin gastrokinetic action in patients with neurogenic gastroparesis," Peptides, vol. 27, no. 7, pp. 1603-1606, 2006.

[61] J. Tack, I. Depoortere, R. Bisschops, K. Verbeke, J. Janssens, and T. Peeters, "Influence of ghrelin on gastric emptying and meal-related symptoms in idiopathic gastroparesis," Alimentary Pharmacology and Therapeutics, vol. 22, no. 9, pp. 847853, 2005.

[62] K. Venkova, G. Fraser, H. R. Hoveyda, and B. GreenwoodVan Meerveld, "Prokinetic effects of a new ghrelin receptor agonist TZP-101 in a rat model of postoperative ileus," Digestive Diseases and Sciences, vol. 52, no. 9, pp. 2241-2248, 2007. 
[63] K. C. Lasseter, L. Shaughnessy, D. Cummings, et al., "Ghrelin agonist (TZP-101): safety, pharmacokinetics and pharmacodynamic evaluation in healthy volunteers: a phase I, first-inhuman study," Journal of Clinical Pharmacology, vol. 48, no. 2, pp. 193-202, 2008.

[64] P. Poitras and C. Tomasetto, "The potential of ghrelin as a prokinetic," Regulatory Peptides, vol. 155, no. 1-3, pp. 24-27, 2009. 

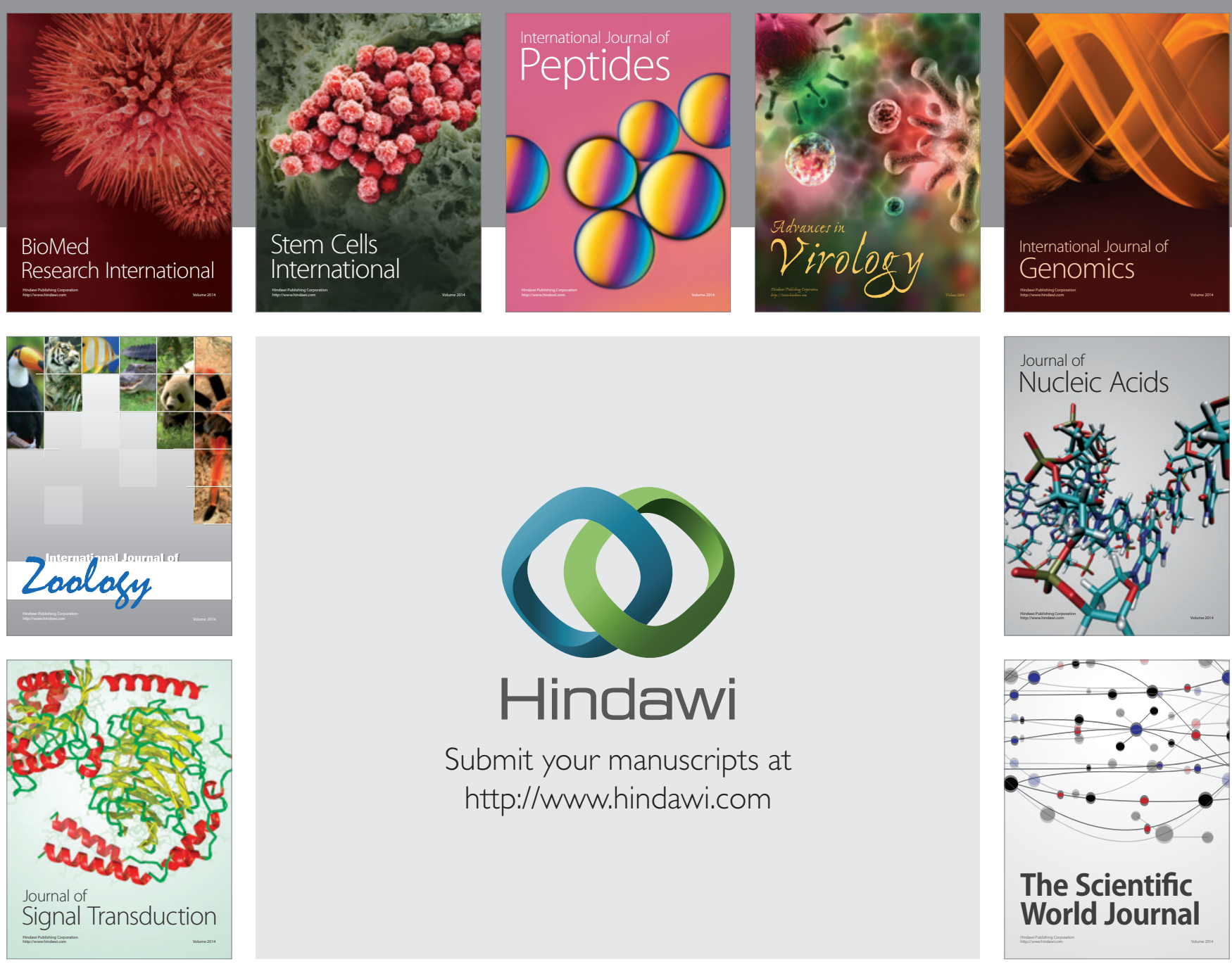

Submit your manuscripts at

http://www.hindawi.com
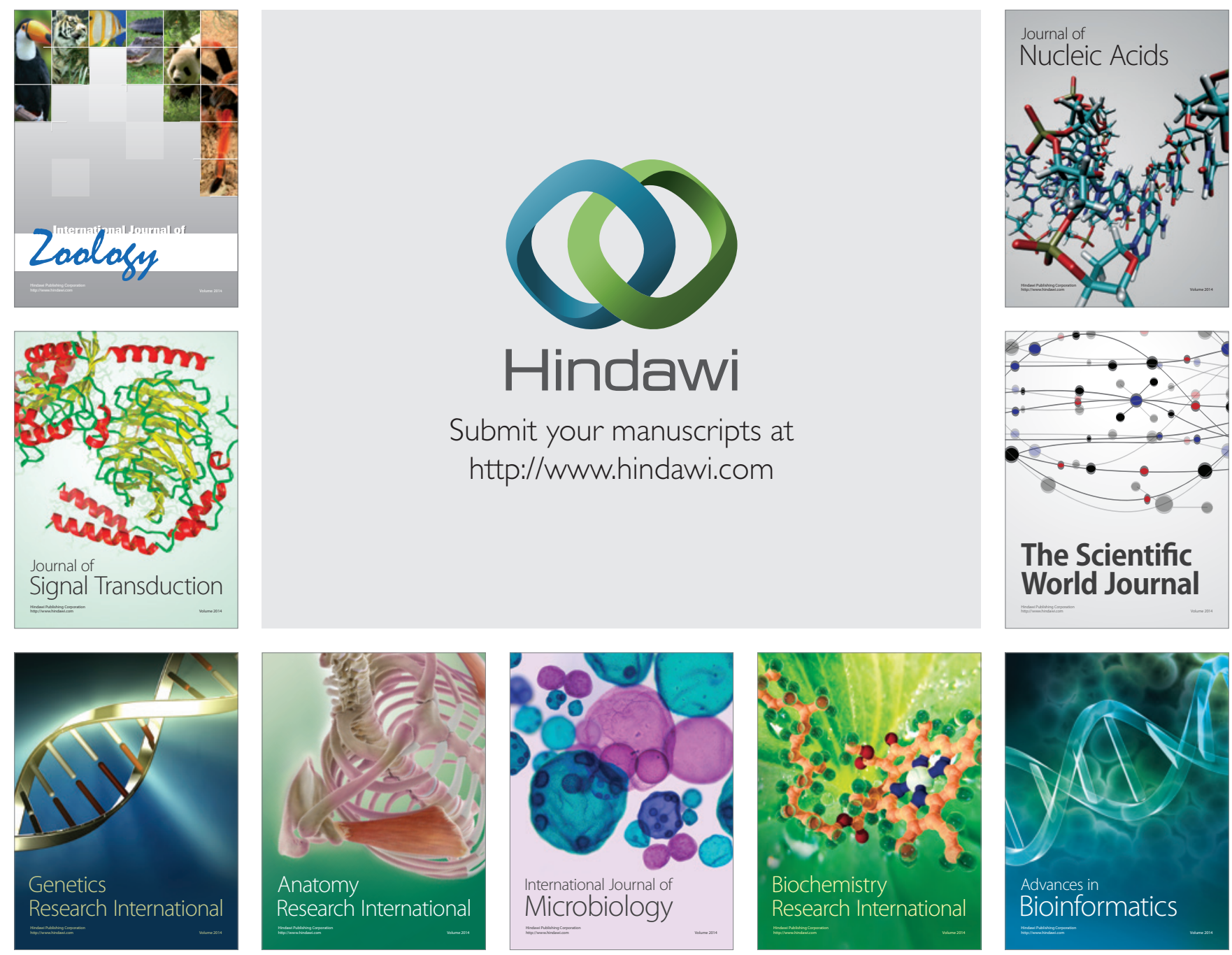

The Scientific World Journal
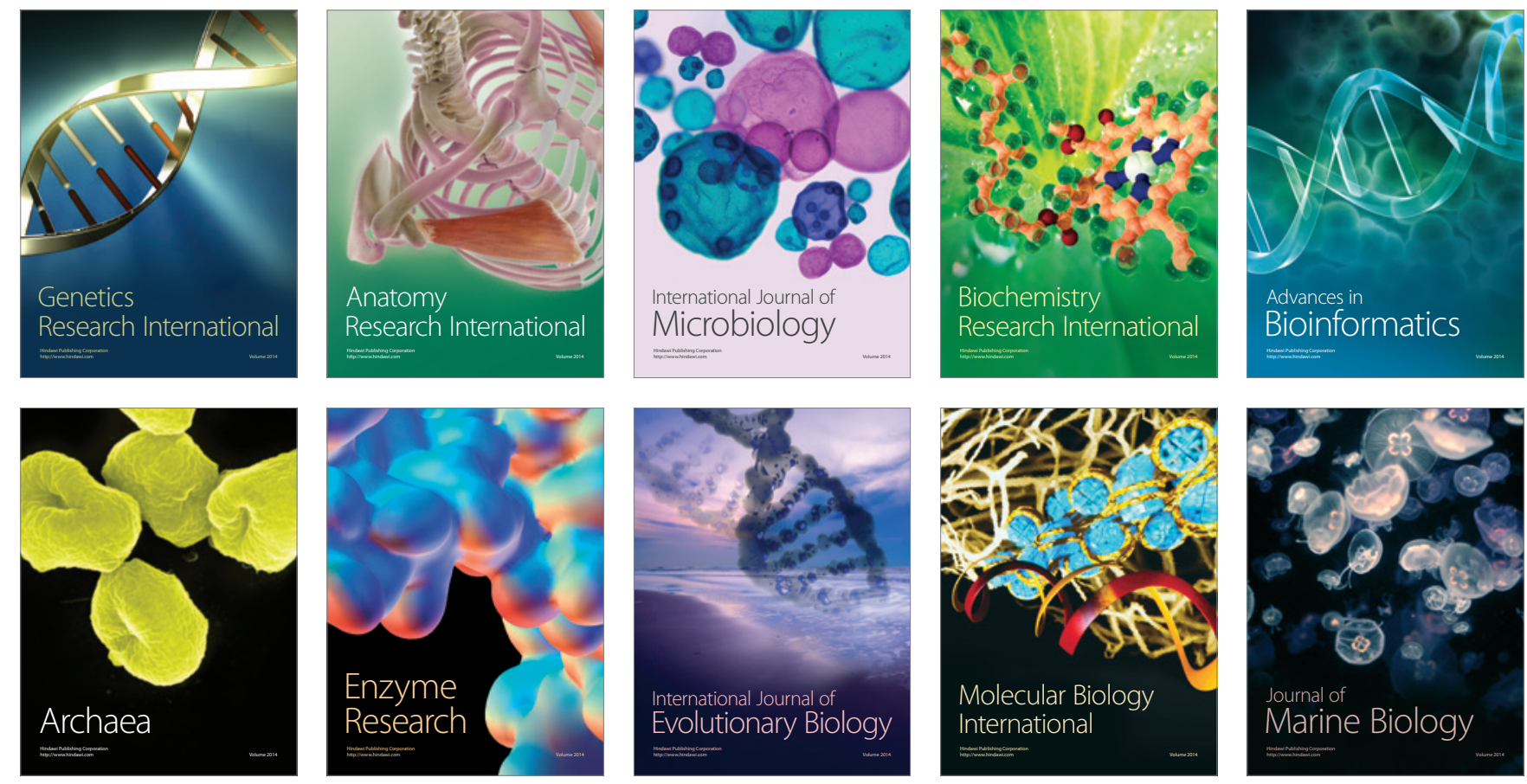